\title{
23. VOLCANIC GLASSES FROM SEDIMENTS FROM SITES 453 AND 454 IN THE MARIANA TROUGH ${ }^{1}$
}

\author{
Gordon H. Packham and Kenneth L. Williams, Department of Geology and Geophysics, \\ University of Sydney, Sydney, Australia
}

\begin{abstract}
Pliocene and Pleistocene volcanic glass fragments from Mariana Trough sediments at Sites 453 (16 samples) and 454 (4 samples), located near the western edge of the trough and just west of the spreading axis, respectively, have been analyzed for major elements with an electron microprobe. They derive from volcanic activity on the present Mariana active arc. The glasses from Site 453 are all tholeiitic with a wide range of $\mathrm{SiO}_{2}$ contents. Those less than $2 \mathrm{~m}$.y. old have slightly lower $\mathrm{TiO}_{2}$ and higher $\mathrm{K}_{2} \mathrm{O}$ contents than the older ones. The glasses from Site 454 are all Pleistocene and resemble the younger glasses at Site 453. Major element compositions of the older basaltic glasses at Site 453 are similar to those of the Mariana Trough basalts drilled on Leg 60. Both older and younger suites of glasses differ from the composition of rocks exposed on the active arc, which are assumed to be younger than any of the samples studied (i.e., about 200,000 y.). A third suite is represented by the arc rocks exposed on the volcanic islands. These have a smaller range of $\mathrm{SiO}_{2}$ contents and contain more $\mathrm{Al}_{2} \mathrm{O}_{3}$ but less $\mathrm{K}_{2} \mathrm{O}, \mathrm{TiO}_{2}$, and $\mathrm{FeO}^{\mathrm{t}}$ (total $\mathrm{Fe}$ as $\mathrm{FeO}$ ) than the sediment glasses studied. Further, a plot of $\mathrm{FeO}^{\mathrm{t}}$ against $\mathrm{MgO}$ for the arc rocks does not follow the island arc tholeite trend of the trough sediment glasses. Using the major element compositions of the arc rocks and sediment glasses, we can recognize three phases of volcanic activity, as indicated. The first evidence of the oldest phase of activity occurs $5 \mathrm{Ma}$, about 4.5 m.y. after the trough started to form. The second commenced about $2 \mathrm{Ma}$, and the last, including present-day activity, began within the last $200,000 \mathrm{y}$. Initially the rocks had major element affinities with the tholeiitic Mariana Trough seafloor, but this influence declined as the trough widened.
\end{abstract}

\section{INTRODUCTION}

Ash deposited in the Mariana Trough provides the most complete record of the post-Miocene history of volcanic activity on the Mariana arc. We examined this record by electron microprobe analysis of glass and mineral grains from the sediments. Since only major elements could be determined, our conclusions are necessarily somewhat limited; the data are further biased to some extent by being restricted to the products of explosive volcanic activity. Products of less violent eruptions are unlikely to be present in the sediments.

The Mariana Trough, which lies between the West Mariana Ridge and the present-day Mariana volcanic arc, is an actively spreading basin that may have begun to form as early as about $9.5 \mathrm{Ma}$, in the late Miocene (Bleil, this volume).

Four sites were drilled in the trough on Leg 60 . Two of them, Sites 453 and 454, are located in sediment ponds to the west of the spreading axis (Fig. 1) and Sites 454 and 455 are to the east of it. Site 455 is located on the western edge of the sediment apron spilling down from the active arc, and Site 456 is on a small ridge 21 $\mathrm{km}$ farther west. The sequence at Hole 453 was the most complete trough succession drilled, containing a continuous record of the arc volcanism back to the base of the Pliocene $(5 \mathrm{Ma})$. The site is located about $25 \mathrm{~km}$ from the western edge of the trough, about $245 \mathrm{~km}$ west of the active arc. Site $454,140 \mathrm{~km}$ west of the active arc, is about $25 \mathrm{~km}$ to the west of the present suspected

\footnotetext{
1 Initial Reports of the Deep Sea Drilling Project, Volume 60
}

spreading axis. The oldest sediments drilled there are early Pleistocene volcaniclastic debris that was interbedded with basalt flows. Sixteen samples were examined from Site $453 ; 14$ of them are glass-bearing. We studied four glass-bearing samples from Site 454. No samples were analyzed from Sites 455 and 456 , on the eastern side of the spreading ridge of the trough. The section drilled in Site 455 holes was almost entirely upper Pleistocene, and the sediments in Site 456 holes were all Pleistocene and more altered than elsewhere except for the youngest layers.

The sediment ponds at Sites 453 and 454 are surrounded by rough topography, and the detritus has reached the pond by transportation through the air or, in the case of highly pumiceous fragments, flotation. The deposits therefore represent the products of explosive volcanic activity. At Site 453 the bedding is well preserved in the cores, and it is evident that deposition has been cyclic, with graded units being separated by strongly bioturbated intervals. The graded intervals were rapidly deposited, either by ash falls or by redeposition from the surrounding ridges, or by a combination of both. Ash fall rather than redeposition was the more important process, since significant changes in composition occur from one sample to the next. The sediment accumulation rate decreases approximately exponentially upward through the column, which can be attributed to the linear increase with time of the distance of the arc from the site (see Site 453 site chapter, this volume).

The source of the ash throughout is assumed to be the arc on the eastern margin of the Mariana Trough, because drilling on the eastern side of the West Mariana 


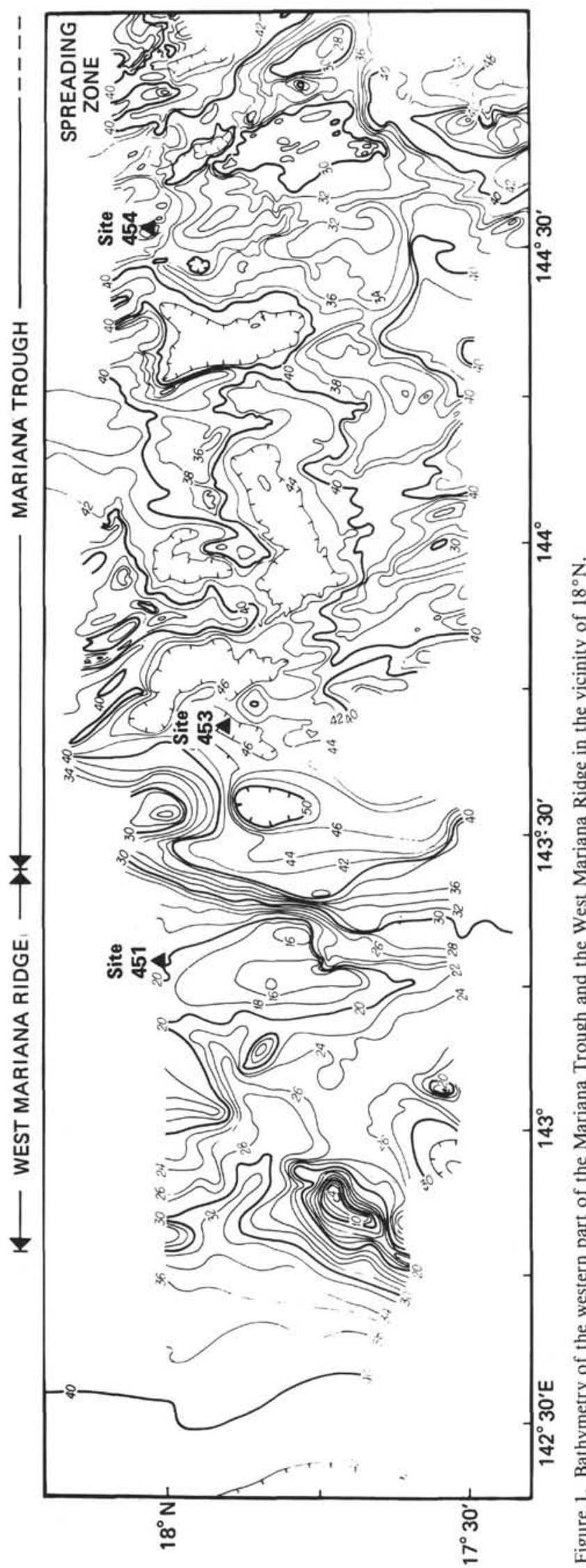

Ridge (Site 451), $45 \mathrm{~km}$ west of Site 453 , shows (Fig. 1) abundant ridge vulcanism to have continued until 9.5 $\mathrm{Ma}$, with 740 meters of volcanic debris accumulating in the previous 1.5 m.y. (mostly calc-alkalic basalts and a few andesites). During the next 4.5 m.y. another 125 meters of tuff and breccia accumulated (Scott et al., 1980). The West Mariana arc vulcanism appears then to have been waning during the early stages of formation of the Mariana Trough. The volcanoes were located on the west flank of the West Mariana Ridge. The youngest volcanic sediments $(0.5 \mathrm{~m} . \mathrm{y}$. old $)$, consisting of interbedded ashes and oozes, are overlain by Pliocene oozes with a minor ash component (Scott et al., 1980). The ash component of the Pliocene to Pleistocene oozes was presumed by Leg 59 shipboard scientists to be derived from the present active arc. The oldest sediments of Site 453 are oldest Pliocene and hence younger than the least volcanic units at Site 451 . They rest on a breccia probably derived from an eastward projection of the West Mariana Ridge (Fig. 1). This projection may be bounded on the south by a transform fault. The basement at Site 453 is assumed, from physiography and magnetic profiles, to be part of the Mariana Trough.

\section{LABORATORY PROCEDURE}

A sample of 1 to 2 cubic centimeters was immersed in distilled water and disaggregated by stirring or ultrasonic vibration. The coarser fraction was concentrated by decantation of the supernatant liquid; the process was repeated until all the fines were removed. The coarser fraction was then mounted and polished, and glass particles were identified by optical microscopy and analyzed with an Etec Autoprobe electron microprobe. In order to reduce apparent loss of alkalis (especially sodium) from the glasses as a consequence of diffusion, charging, or evaporation under the beam, the analyses were carried out at $14 \mathrm{kV}$, with a specimen current of $20 \mathrm{nA}, 20 \mathrm{~s}$ counting times, and a beam diameter of approximately $10 \mu \mathrm{m}$. Repeated measurements under these conditions showed no significant deterioration in alkali count rates. As an added precaution, sodium was always among the first group of elements determined. Despite these precautions however, some of the analyses of the acid glasses gave low totals and low sodium values, for which hydration and leaching are presumed to be responsible. $\mathrm{Na}_{2} \mathrm{O}$ shows increased scatter at high silica values, especially in the deeper parts of Hole 453.

\section{SITE 453}

Over 130 analyses of glasses (Table 1) were obtained from 16 samples from Hole 453, from Cores 1 to 42 (Fig. 2). The glasses in Cores 43 to 48, at the bottom of the sediment column, are highly altered. A second zone of alteration occurs from the lower part of Core 14 to the bottom of Core 18. This higher zone corresponds to an interval of slower sedimentation (Fig. 3).

The glasses show a wide, more or less evenly distributed range of silica contents from 49 to $73 \%$ (Fig. 4), with some tendency to cluster in the $52-57,62-65$, and $70-72 \%$ intervals.

Changes with time in the distribution of silica contents (Figs. 3 and 4) correspond with two phases of vulcanism that can be identified in the samples, the first from at least $4.8 \mathrm{Ma}$ (the age of the oldest sample suitable for study) to about $2.5 \mathrm{Ma}$ and the second from about $2.0 \mathrm{Ma}$ to the age of the youngest sample studied (about $0.2 \mathrm{Ma}$ ). The interval between the two phases coincides with a minimum in the sedimentation rate 
Table 1. Microprobe analyses of glass grains from Site 453 sediments, Hole 453.

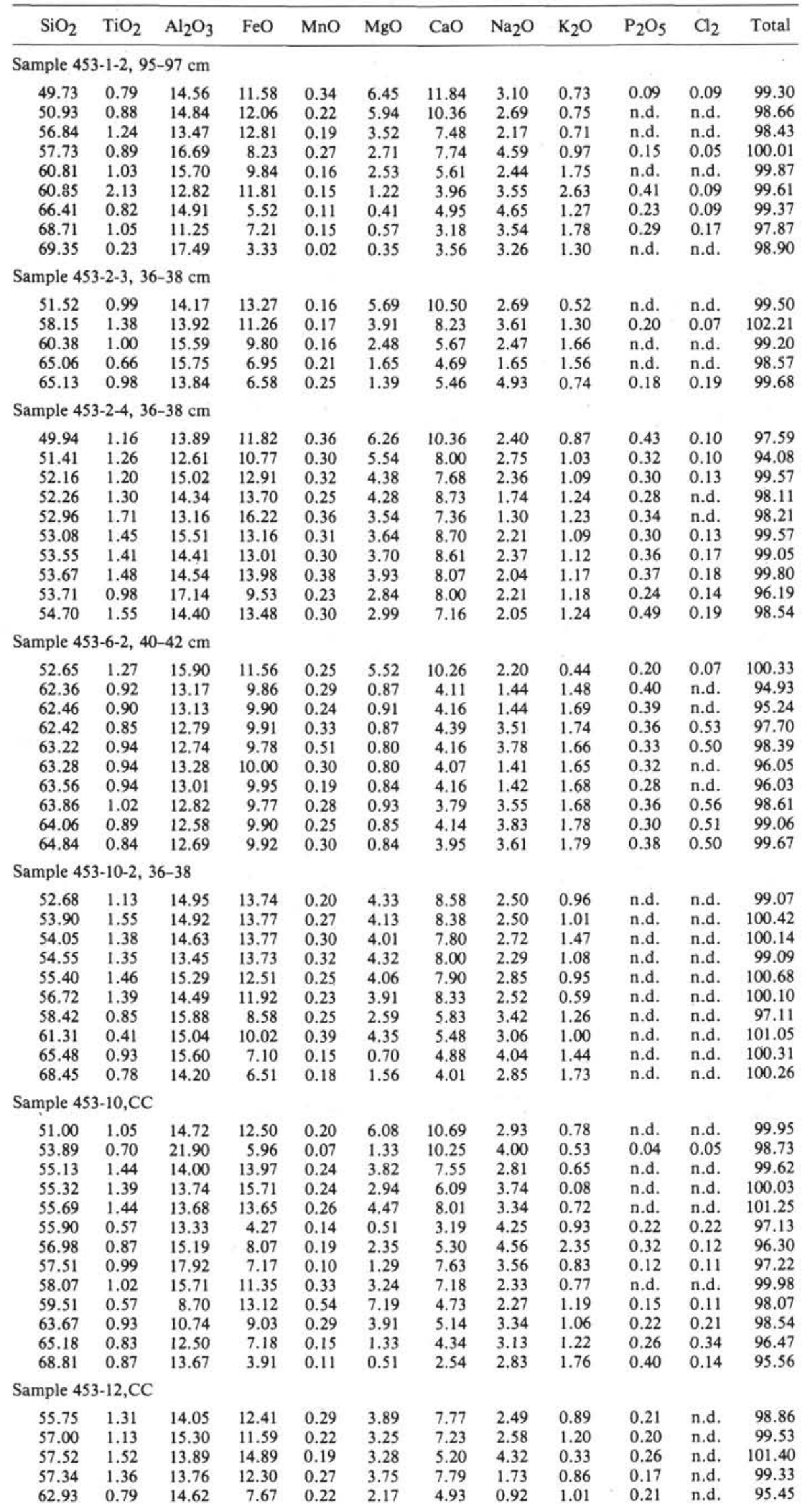


Table 1. (Continued).

\begin{tabular}{|c|c|c|c|c|c|c|c|c|c|c|c|}
\hline $\mathrm{SiO}_{2}$ & $\mathrm{TiO}_{2}$ & $\mathrm{Al}_{2} \mathrm{O}_{3}$ & $\mathrm{FeO}$ & $\mathrm{MnO}$ & $\mathrm{MgO}$ & $\mathrm{CaO}$ & $\mathrm{Na}_{2} \mathrm{O}$ & $\mathrm{K}_{2} \mathrm{O}$ & $\mathrm{P}_{2} \mathrm{O}_{5}$ & $\mathrm{Cl}_{2}$ & Total \\
\hline \multicolumn{12}{|c|}{ Sample $453-18, \mathrm{C}$} \\
\hline 50.98 & 0.71 & 14.67 & 8.62 & 0.26 & 8.67 & 13.38 & 1.94 & 0.27 & 0.12 & n.d. & 99.62 \\
\hline 51.58 & 0.71 & 14.56 & 8.63 & 0.19 & 8.27 & 13.35 & 1.92 & 0.20 & 0.06 & n.d. & 99.47 \\
\hline 51.69 & 0.65 & 18.18 & 7.44 & 0.18 & 5.55 & 12.59 & 2.56 & 0.25 & 0.12 & n.d. & 99.21 \\
\hline 52.37 & 0.86 & 14.83 & 10.11 & 0.20 & 6.63 & 11.31 & 2.19 & 0.26 & 0.03 & n.d. & 98.80 \\
\hline 55.66 & 0.62 & 15.20 & 9.07 & 0.25 & 7.72 & 12.23 & 2.01 & 0.23 & 0.07 & n.d. & 99.06 \\
\hline 71.53 & 0.25 & 12.11 & 2.53 & 0.19 & 0.37 & 2.13 & 1.93 & 1.19 & 0.06 & n.d. & 92.32 \\
\hline 71.62 & 0.29 & 11.62 & 2.28 & 0.18 & 0.24 & 1.89 & 1.69 & 1.19 & 0.08 & n.d. & 91.13 \\
\hline 72.50 & 0.20 & 12.31 & 2.44 & 0.11 & 0.28 & 1.79 & 0.76 & 0.42 & n.d. & n.d. & 90.81 \\
\hline 72.60 & 0.24 & 12.17 & 2.26 & 0.11 & 0.22 & 1.63 & 1.01 & 0.62 & 0.02 & n.d. & 90.88 \\
\hline 72.61 & 0.33 & 11.52 & 2.26 & 0.16 & 0.25 & 1.83 & 1.95 & 1.22 & 0.03 & n.d. & 90.87 \\
\hline 73.15 & 0.20 & 11.93 & 2.25 & 0.10 & 0.18 & 1.54 & 0.54 & 0.36 & 0.06 & n.d. & 90.31 \\
\hline \multicolumn{12}{|c|}{ Sample 453-21,CC, 9-10 cm } \\
\hline 71.58 & 0.40 & 12.40 & 2.68 & 0.13 & 0.40 & 2.01 & 0.69 & 0.34 & 0.06 & n.d. & 90.67 \\
\hline 72.74 & 0.35 & 12.59 & 2.59 & 0.12 & 0.41 & 2.17 & 1.44 & 0.49 & 0.04 & n.d. & 92.95 \\
\hline \multicolumn{12}{|c|}{ Sample $453-24-2,47-48 \mathrm{~cm}$} \\
\hline 51.83 & 1.30 & 16.31 & 8.11 & 0.18 & 6.55 & 10.14 & 3.88 & 0.27 & 0.02 & 0.04 & 98.81 \\
\hline 64.20 & 0.65 & 12.65 & 4.56 & 0.17 & 1.07 & 3.53 & 2.60 & 0.88 & 0.17 & 0.02 & 90.69 \\
\hline 64.58 & 0.74 & 13.51 & 6.00 & 0.19 & 1.10 & 3.85 & 3.67 & 1.04 & 0.20 & 0.25 & 95.13 \\
\hline 64.80 & 0.65 & 12.77 & 5.49 & 0.25 & 0.83 & 3.18 & 2.54 & 1.12 & 0.23 & 0.26 & 92.14 \\
\hline 64.61 & 0.71 & 13.01 & 4.52 & 0.19 & 1.06 & 3.75 & 2.66 & 0.88 & 0.19 & 0.18 & 91.77 \\
\hline 65.54 & 0.64 & 13.69 & 4.31 & 0.17 & 0.98 & 3.55 & 1.09 & 0.66 & 0.17 & n.d. & 90.84 \\
\hline 65.89 & 0.49 & 12.94 & 4.13 & 0.12 & 0.64 & 3.08 & 3.35 & 0.86 & 0.12 & 0.20 & 91.82 \\
\hline 67.39 & 0.64 & 13.10 & 5.40 & 0.15 & 0.68 & 3.03 & 3.27 & 1.43 & 0.24 & 0.20 & 95.54 \\
\hline 67.71 & 0.55 & 13.19 & 4.43 & 0.18 & 0.89 & 3.28 & 2.54 & 1.12 & 0.18 & 0.18 & 94.25 \\
\hline 68.46 & 0.51 & 12.61 & 3.54 & 0.15 & 0.55 & 2.61 & 2.18 & 1.13 & 0.14 & 0.19 & 92.07 \\
\hline 70.83 & 0.46 & 12.05 & 3.71 & 0.16 & 0.17 & 2.03 & 2.98 & 2.22 & 0.01 & 0.17 & 94.79 \\
\hline \multicolumn{12}{|c|}{ Sample $453-27-2,21-23 \mathrm{~cm}$} \\
\hline 52.19 & 0.89 & 14.57 & 11.37 & 0.21 & 6.47 & 11.29 & 2.47 & 0.44 & 0.14 & n.d. & 99.92 \\
\hline 54.00 & 1.50 & 13.37 & 12.52 & 0.24 & 3.61 & 7.69 & 3.16 & 1.09 & 0.28 & 0.16 & 97.63 \\
\hline 55.31 & 1.22 & 14.00 & 11.56 & 0.23 & 3.77 & 8.62 & 2.76 & 0.70 & 0.19 & 0.14 & 98.50 \\
\hline 56.10 & 1.03 & 14.87 & 11.60 & 0.30 & 3.53 & 7.65 & 3.01 & 0.60 & 0.15 & 0.21 & 99.05 \\
\hline 59.86 & 0.80 & 14.56 & 6.57 & 0.17 & 1.67 & 4.79 & 3.33 & 0.92 & 0.22 & 0.16 & 93.03 \\
\hline 60.68 & 0.81 & 14.07 & 5.99 & 0.17 & 1.20 & 4.15 & 2.63 & 0.89 & 0.24 & 0.18 & 91.00 \\
\hline 62.36 & 0.54 & 14.57 & 4.99 & 0.18 & 0.96 & 3.94 & 2.68 & 1.03 & 0.18 & 0.20 & 91.63 \\
\hline 65.86 & 0.52 & 12.85 & 4.89 & 0.13 & 0.65 & 2.87 & 2.52 & 1.02 & 0.09 & 0.27 & 91.41 \\
\hline \multicolumn{12}{|c|}{ Sample 453-29,CC } \\
\hline 58.98 & 0.78 & 14.77 & 7.62 & 0.02 & 1.96 & 5.16 & 0.96 & 0.50 & 0.26 & n.d. & 91.19 \\
\hline 59.17 & 0.57 & 19.21 & 5.51 & 0.12 & 1.16 & 7.15 & 3.00 & 0.39 & 0.14 & n.d. & 96.42 \\
\hline 62.18 & 0.92 & 14.20 & 7.94 & 0.14 & 1.62 & 4.99 & 0.87 & 0.64 & 0.12 & n.d. & 93.62 \\
\hline 62.26 & 0.73 & 14.19 & 7.47 & 0.17 & 1.45 & 4.38 & 0.32 & 0.29 & 0.13 & n.d. & 91.42 \\
\hline 62.53 & 0.87 & 12.12 & 7.98 & 0.19 & 1.91 & 5.26 & 0.65 & 0.99 & 0.12 & n.d. & 95.62 \\
\hline 63.25 & 0.75 & 13.86 & 8.11 & 0.16 & 1.54 & 4.50 & 0.86 & 0.42 & 0.16 & n.d. & 93.61 \\
\hline 63.33 & 1.65 & 13.26 & 12.48 & 0.16 & 0.59 & 3.00 & 2.36 & 0.08 & 0.18 & n.d. & 97.79 \\
\hline 64.08 & 0.92 & 14.96 & 8.79 & 0.21 & 1.89 & 5.41 & 1.93 & 0.95 & 0.18 & n.d. & 99.33 \\
\hline 71.02 & 0.72 & 14.06 & 2.86 & 0.02 & 0.77 & 3.35 & 3.55 & 1.36 & 0.23 & n.d. & 97.96 \\
\hline 71.49 & 0.53 & 13.50 & 4.71 & 0.15 & 0.72 & 2.44 & 4.52 & 1.40 & 0.02 & n.d. & 99.47 \\
\hline \multicolumn{12}{|c|}{ Sample $453-33-2,71-72 \mathrm{~cm}$} \\
\hline 53.63 & 1.22 & 13.90 & 12.6 & 0.22 & 4.5 & 8.66 & 2.94 & 0.64 & n.d. & n.d. & 98.43 \\
\hline & 0.98 & 47 & 11.00 & 0.2 & 3.3 & 7.62 & 3.3 & 0.6 & 0.04 & 0.16 & 97.04 \\
\hline 56.35 & 1.18 & 14.64 & 11.74 & 0.14 & 3.78 & 7.79 & 2.62 & 0.72 & n.d. & n.d. & 98.96 \\
\hline 64.83 & 0.44 & 12.87 & 4.64 & 0.20 & 0.65 & 3.10 & 2.61 & 0.95 & 0.04 & 0.23 & 90.56 \\
\hline \multicolumn{12}{|c|}{ Sample $453-42-2,6-7 \mathrm{~cm}$} \\
\hline 52.97 & 1.04 & 14.00 & 11.28 & 0.24 & 5.29 & 9.85 & 2.45 & 0.50 & 0.13 & n.d. & 97.75 \\
\hline & 0.94 & 18.36 & 7.84 & 0.22 & 2.35 & 10.83 & 3.5 & 0.50 & 0.11 & n.d. & 97.79 \\
\hline 54.69 & 1.12 & 12.46 & 12.61 & 0.31 & 4.67 & 8.49 & 2.6 & 0.81 & 0.12 & n.d. & 97.88 \\
\hline 55.12 & 1.54 & 15.28 & 8.31 & 0.24 & 4.66 & 8.52 & 3.66 & 0.39 & 0.19 & n.d. & 97.89 \\
\hline 60.14 & 1.01 & 12.98 & 8.19 & 0.24 & 2.37 & 5.23 & 4.38 & 0.78 & 0.22 & n.d. & 95.54 \\
\hline 61.29 & 0.72 & 14.65 & 6.48 & 0.27 & 1.69 & 6.00 & 1.81 & 0.74 & 0.18 & n.d. & 93.83 \\
\hline 63.01 & 0.96 & 12.94 & 9.55 & 0.23 & 0.85 & 4.11 & 1.17 & 1.48 & 0.33 & n.d. & 94.55 \\
\hline 65.61 & 0.86 & 14.28 & 6.60 & 0.39 & 1.49 & 5.25 & 4.62 & 0.72 & 0.18 & n.d. & 99.99 \\
\hline 67.81 & 0.95 & 12.31 & 5.98 & 0.16 & 0.64 & 4.35 & 3.52 & 1.49 & 0.26 & n.d. & 97.47 \\
\hline 73.09 & 0.10 & 13.83 & 1.63 & 0.11 & 0.84 & 6.60 & 3.11 & 0.20 & 0.06 & n.d. & 99.56 \\
\hline
\end{tabular}


(Fig. 3). The overall decline in sedimentation rate up the hole is largely explained by the progressively increasing distance between the site and the arc. The minimum between 2.0 and $2.5 \mathrm{Ma}$ reflects changes in volcanic productivity from the arc and also seems to mark small but significant changes in the compositions of the volcanic products.

The glass compositions fall almost exclusively into the tholeiitic fields of an AFM diagram (Fig. 5). Major element abundances in the two phases are closely related, but some significant variations also seem to occur within and between the two phases.

In each phase there is a poorly defined trend to diversification in the distribution of silica contents (Fig. 3). These span a relatively wide range at the base of the phase but tend toward bimodal distributions higher in the cores, with a gap developing between 55 and $60 \%$ $\mathrm{SiO}_{2}$. Although these trends are not clearly established by the relatively limited number of samples so far examined, they appear nevertheless to be closely related to changes in the sedimentation rate and thus to reflect systematic changes in the nature of the volcanic processes within each phase.

In the older phase, $\mathrm{Al}_{2} \mathrm{O}_{3}$ ranges from 11 to $16 \%$, with a slight tendency to decline with increasing $\mathrm{SiO}_{2}$ (Fig. 6); in the younger phase $\mathrm{Al}_{2} \mathrm{O}_{3}$ concentrations (Fig. 7) are slightly higher overall (except for a few extreme values), with a less pronounced decline in the high silica glasses. Glasses of the older phase similarly have slightly lower $\mathrm{K}_{2} \mathrm{O}$ contents, ranging typically from less than $0.5 \%$ at $51 \% \mathrm{SiO}_{2}$ to an average of less than $1.3 \% \mathrm{~K}_{2} \mathrm{O}$ at $72 \% \mathrm{SiO}_{2}$. By comparison, potash in the younger glasses ranges from about $0.8 \%$ at $51 \% \mathrm{SiO}_{2}$ to about $1.7 \%$ at $69 \% \mathrm{SiO}_{2}$.

$\mathrm{Na}_{2} \mathrm{O}$ shows considerable scatter, particularly in the older phase, but averages around $3 \%$, with a very slight tendency to increase toward higher silica contents when analyses with poor totals are excluded. There is little if any significant difference between the $\mathrm{Na}_{2} \mathrm{O}$ distributions in the two phases.

$\mathrm{CaO}$ decreases markedly with increasing $\mathrm{SiO}_{2}$ in both phases but appears to be significantly higher in the low silica glasses of the older phase $\left(12 \%\right.$ at $51 \% \mathrm{SiO}_{2}$ by comparison with $10 \%$ at $51 \% \mathrm{SiO}_{2}$ in the younger phase) but not in the high silica glasses (approximately $4 \%$ $\mathrm{CaO}$ at $66 \% \mathrm{SiO}_{2}$ in both phases).

Total iron, expressed as $\mathrm{FeO}$ in Figures 6 and 7, decreases with increasing $\mathrm{SiO}_{2}$ in both phases. But iron contents are generally slightly higher in the basic glasses of the younger phase (averaging $12.5 \%$ at $55 \% \mathrm{SiO}_{2}$ compared to $10.5 \%$ at $55 \% \mathrm{SiO}_{2}$ in the older glasses). Glasses of the older phases also show more pronounced depletion in iron content in samples containing less than $55 \% \mathrm{SiO}_{2}\left(9 \% \mathrm{FeO}\right.$ at $51 \% \mathrm{SiO}_{2}$ compared with $12.8 \%$ $\mathrm{FeO}$ at $51 \% \mathrm{SiO}_{2}$ in the younger glasses).

$\mathrm{TiO}_{2}$ distributions are broadly similar to those of iron, with a maximum in each case between 55 and $60 \%$ $\mathrm{SiO}_{2}$ and slightly higher overall concentrations in the younger phase (averaging $1.3 \%$ at $55 \% \mathrm{SiO}_{2}$ compared to $1.0 \% \mathrm{TiO}_{2}$ at $55 \% \mathrm{SiO}_{2}$ in the older glasses).
$\mathrm{MgO}$ decreases with increasing $\mathrm{SiO}_{2}$ in both cases, but the first phase samples contain significantly higher $\mathrm{MgO}$ contents in the more basic glasses (almost $9 \%$ $\mathrm{MgO}$ at $51 \% \mathrm{SiO}_{2}$ compared to $5 \% \mathrm{MgO}$ at $51 \% \mathrm{SiO}_{2}$ in the younger glasses).

Differences in $\mathrm{MgO}$ and $\mathrm{FeO}$ distributions are emphasized in plots of $\mathrm{Fe}$ (total as $\mathrm{FeO}$ ) $/ \mathrm{MgO}$ vs. $\mathrm{SiO}_{2}$ (Figs. 8 and 9) and $\mathrm{FeO}^{\mathrm{t}}$ vs. $\mathrm{MgO}$ (Fig. 10). In the older glasses the $\mathrm{FeO}^{t} / \mathrm{MgO}$ ratio averages 1.5 at $51 \% \mathrm{SiO}_{2}$ and increases steadily to about 5.0 at $70 \% \mathrm{SiO}_{2}$. Glasses of the younger phase have higher $\mathrm{FeO}^{\mathrm{t}} / \mathrm{MgO}$ ratios in the more basic compositions $\left(2.5\right.$ at $\left.51 \% \mathrm{SiO}_{2}\right)$, also increasing steadily to about 3.3 at $55 \% \mathrm{SiO}_{2}$. The more acid of the younger glasses, however, then appear to divide into two populations, one with $\mathrm{FeO}^{\mathrm{t}} / \mathrm{MgO}$ ratios averaging about 5.0 at $68 \% \mathrm{SiO}_{2}$ and the other averaging about 12.0 at $66 \% \mathrm{SiO}_{2}$. The latter group has no analog in the early phase, apart from a few samples which yielded analyses of poor quality.

$\mathrm{FeO}^{\mathrm{t}}$ versus $\mathrm{MgO}$ plots (Fig. 10) emphasize the differences between the compositions of the glasses on one hand and the arc rocks on the other.

In addition to the glasses, 16 pyroxene and 55 plagioclase grains were analyzed, and quartz was also identified in samples from Cores 29, 21, and 18 .

In the two volcanic phases represented at this site, two pyroxene types are present in the samples: diopsideaugite and pigeonite-hypersthene (Fig. 11; Table 2). In the older phase, diopside was identified in the two lowest samples-i.e., from Cores 42 and 37 -and the remainder of the calcic pyroxenes fall into the augite field. The calcium-poor pyroxenes contain about $1.5 \% \mathrm{CaO}$. The calcic pyroxenes from the younger phase are augites, but they include some poorer in calcium than those of the older phase. Two of these low Ca pyroxenes were analyzed, one plotting as a hypersthene and the other as an intermediate pigeonite. All the pyroxenes analysed have low $\mathrm{Al}_{2} \mathrm{O}_{3}$ and $\mathrm{TiO}_{2}$ contents.

The feldspars are calcic and the compositional distribution of grains is $11 \%$ anorthite, $53 \%$ bytownite, $29 \%$ labradorite, and $7 \%$ andesine. Composition trends that parallel those of the silica contents of the glasses are apparent in the feldspars. The most calcic feldspars (over $\mathrm{An}_{90}$ ) were found in Cores 42,12 , and 10 at the bases of the two phases.

\section{SITE 454}

At Site 45428 glasses were analyzed (Table 3). They were obtained from four samples from Hole 454Afrom Cores 1 and 4 above the basalt and Cores 8 and 13 interbedded with the basalt. Their range in silica content is from $52 \%$ to $65 \%$ with all but three of the samples between $53 \%$ and $58 \%$ corresponding to a broad peak in Site 453 samples (Fig. 4). There are no significant compositional changes between the four samples; all of them would fall within the second volcanic phase represented at Site 453.

Except for iron, the other major elements (Fig. 12) are very similar in distribution to those of the second phase of vulcanism at Site 453. The total iron distribu- 


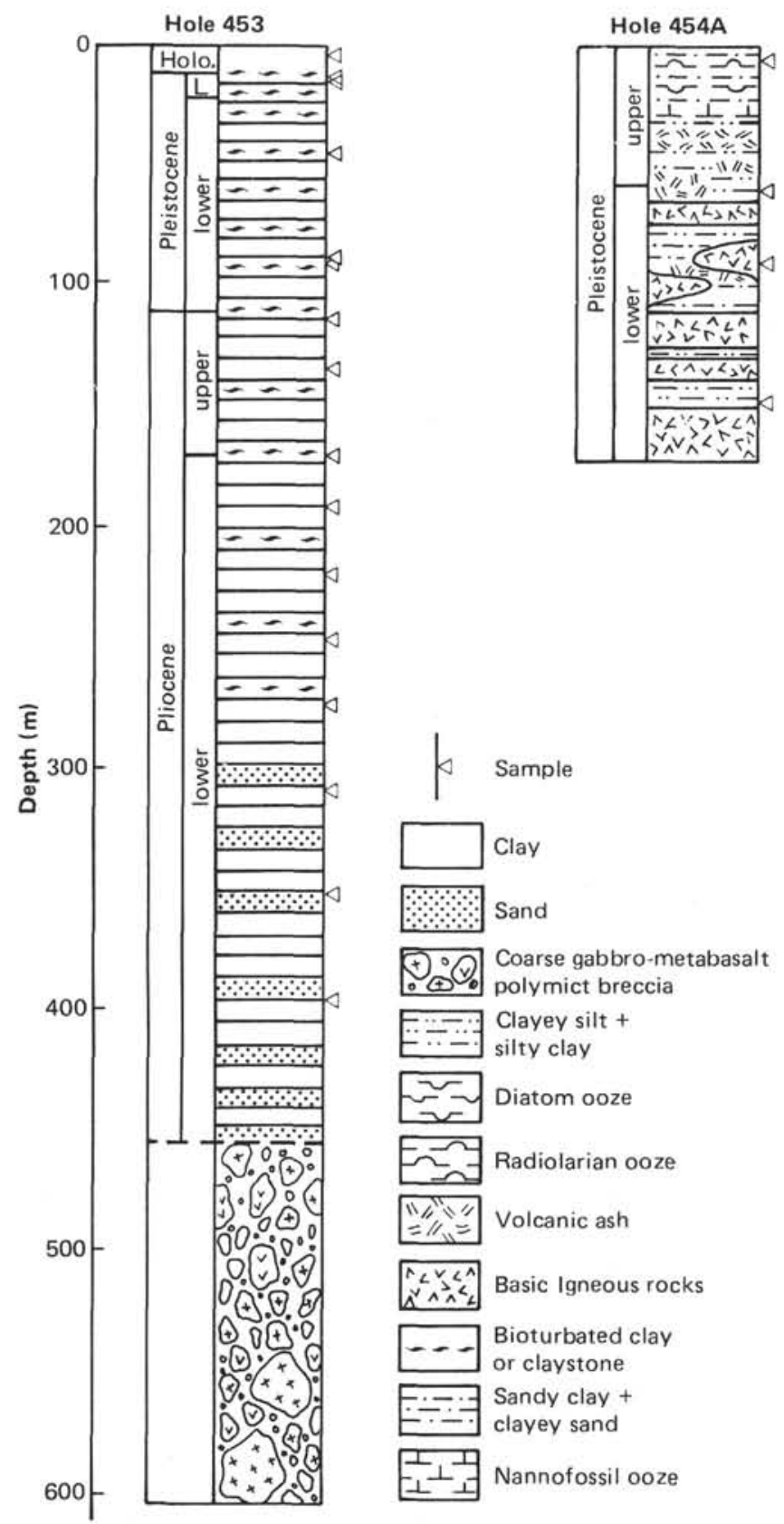

Figure 2. Stratigraphic columns for DSDP Holes 453 and 454A, with depth locations of samples used in this study.

tion resembles that of the first phase, although in the range of 53 to $55 \% \mathrm{SiO}_{2}$ iron content appears to be about $1 \%$ lower than that of the first phase. Further sampling may resolve this discrepancy and fill in the silica range. The $\mathrm{FeO}^{t} / \mathrm{MgO}$ plot falls within the common field of both phases at Site 453 .

\section{DISCUSSION}

The purpose of this discussion is to examine some of the implications of the major element chemistry variation in the glasses from the two sites and to compare it with the seafloor basalts and igneous rocks of the Mariana Islands and with the volcanics of the Tonga

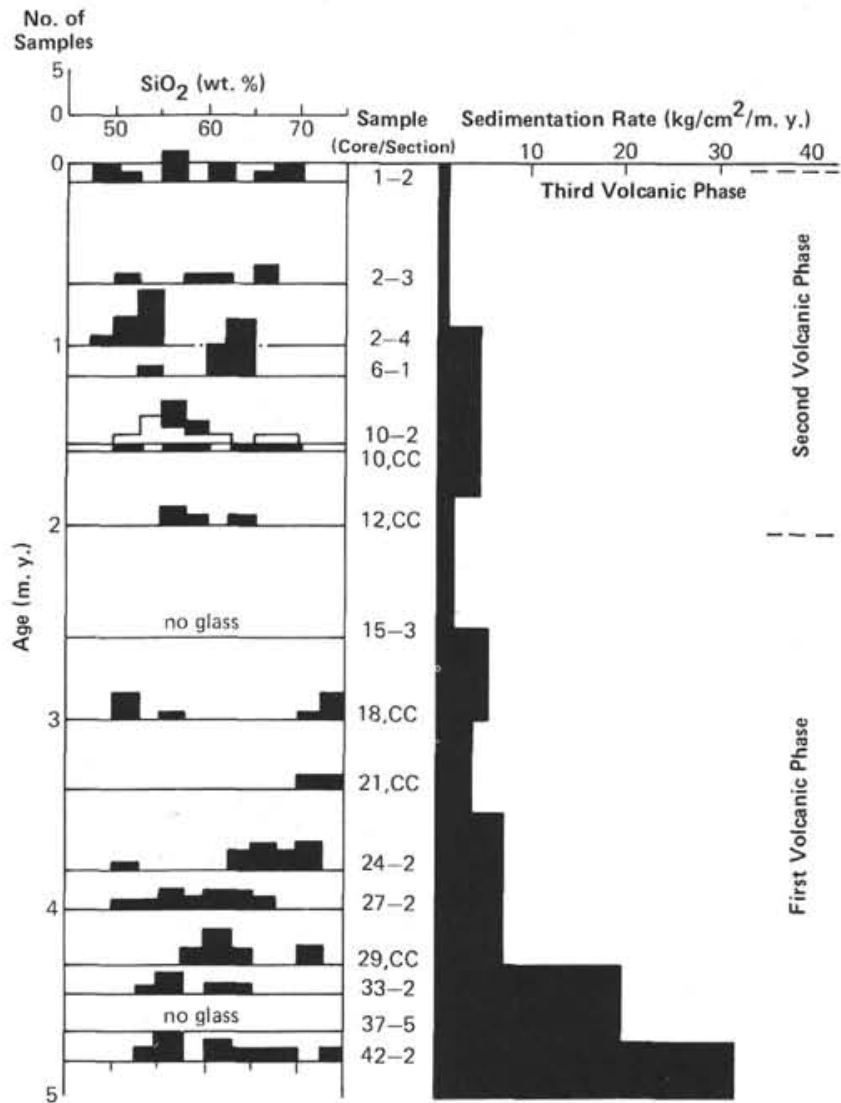

Figure 3. Distribution of weight percentage of silica in volcanic glasses from individual samples from Hole 453 and the estimated sedimentation rate plotted against age of sample.

Arc. Comparison with Tonga is significant because the Tonga Arc has a setting almost identical to that of the Mariana Arc, consisting of an active western Pacific ensimatic volcanic arc and a spreading back-arc basin, beneath which lithosphere of the Pacific plate is being subducted.

The glass shards analyzed are assumed to correspond in composition to whole rocks. If the magma from which the ash was derived was originally aphyric, the compositional similarities should be great; alternatively, if the magma was phyric, the glass would represent a potential rock resulting from fractionation of the phenocrysts. Microprobe analytical data are likely to show more scatter than whole-rock chemical data because of small-scale inhomogeneities in the glass, the extremely small size of the sample, and the presence of microlites. Compositional scattering could also result from the alteration of the glasses on the seafloor and, following burial, from reaction with pore fluids, possibly at elevated temperatures. Considering the potential effect of these factors, the analyses show a surprisingly coherent pattern when the various oxides are plotted against $\mathrm{SiO}_{2}$. Compositional scattering is greatest in the higher silica glasses of the older volcanic phases and is accompanied by low analysis totals and low alkalis, especially $\mathrm{Na}_{2} \mathrm{O}$. The basic glasses of this phase show less scattering and higher totals. Examination of the plots suggests 

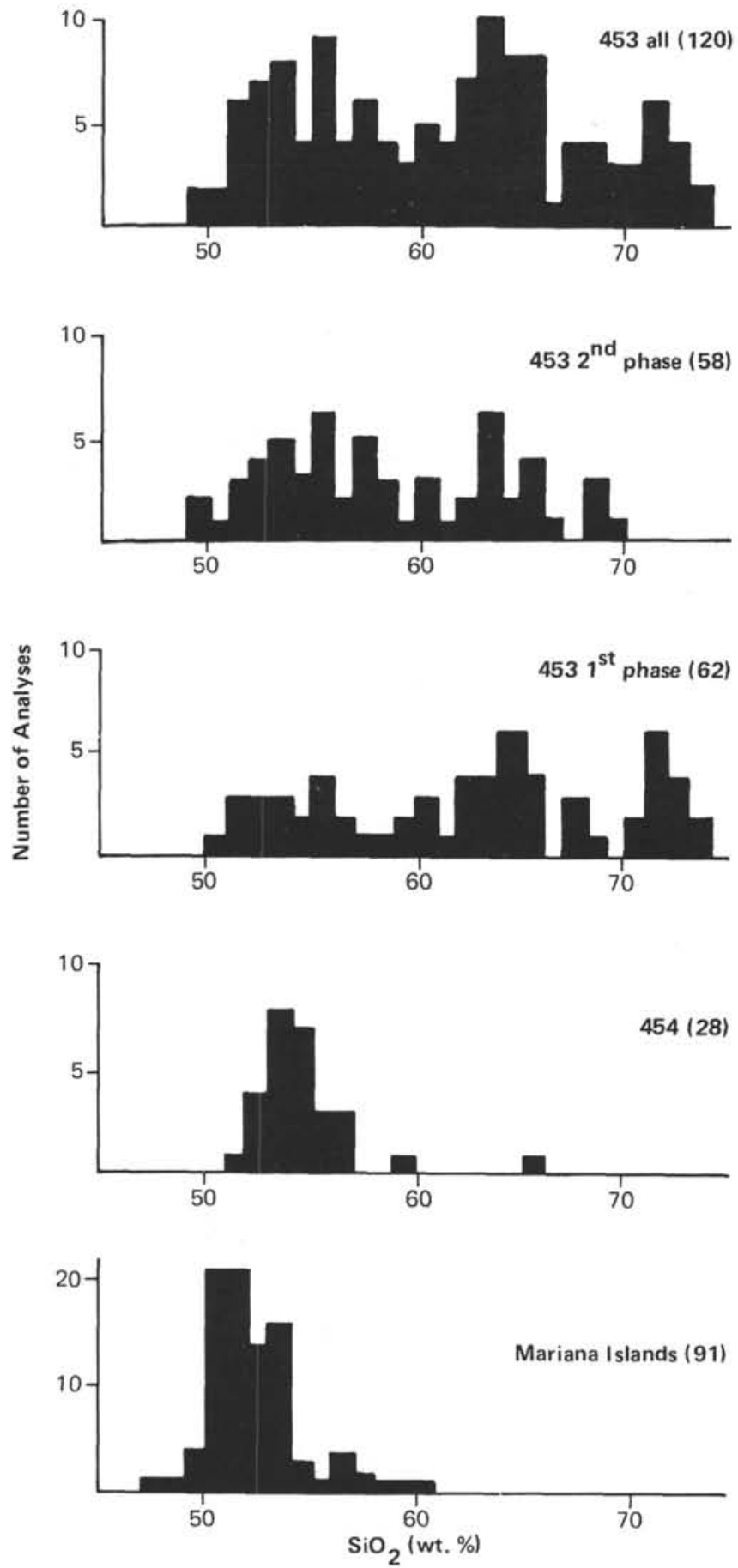

Figure 4. Weight percentage of silica in volcanic glass samples from Holes 453 and 454 , and analyzed rock samples from the active Mariana volcanic arc.

that low-total analyses show depletion to some extent in all oxides, possibly excepting $\mathrm{TiO}_{2}$.

\section{Comparison of the Two Phases at Site 453 and Mariana Trough Seafloor Basalts}

If moderate iron enrichment is taken as a prime criterion, both phases can be considered to contain glasses belonging to the island arc tholeiite series of Jakeš and Gill (1970). They plot on the same field on a

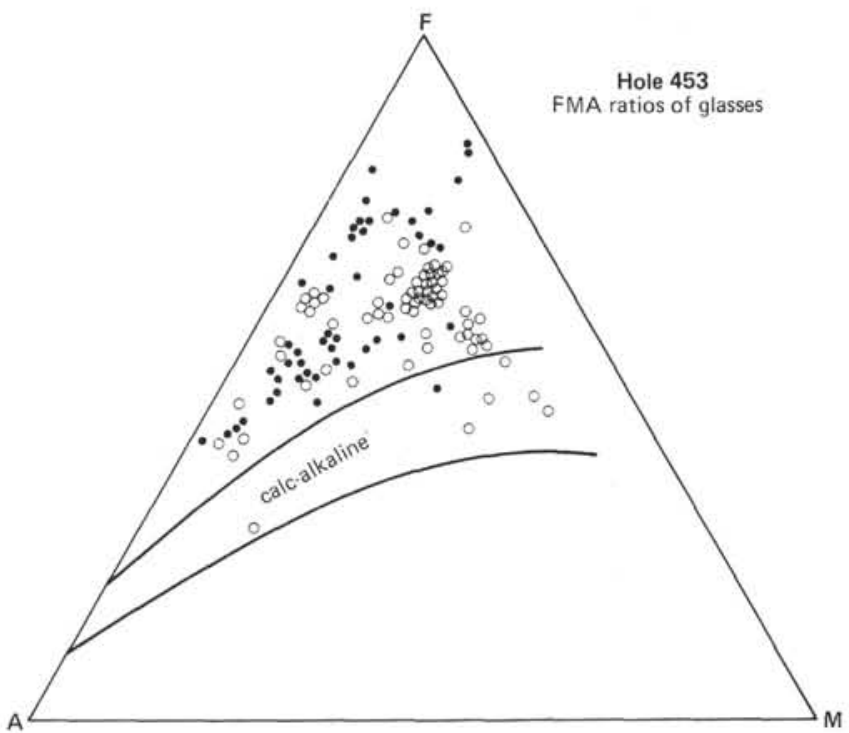

Figure 5. AFM ratios of glass samples from Hole 453. $(\mathrm{O}=$ analyses with totals between 98 and $102,-=$ analyses with totals less than 98.)

$\mathrm{FeO}^{t} / \mathrm{MgO}$ diagram (Fig. 10) and in the tholeiitic field of an AFM diagram (Fig. 5). They also contain, with rare exceptions, less than $16 \% \mathrm{Al}_{2} \mathrm{O}_{3}$. The $\mathrm{K}_{2} \mathrm{O}$ contents of the two phases converge at high $\mathrm{SiO}_{2}$ values and remain below $2 \%$, distinguishing them from calc-alkaline rocks, but the older is much lower at low silica values (about $0.2 \% \mathrm{~K}_{2} \mathrm{O}$ at $52 \% \mathrm{SiO}_{2}$ ) and so resembles abyssal tholeiites. The titania contents of the two phases appear to demonstrate enrichment paralleling that of total iron, with a maximum at $54 \% \mathrm{SiO}_{2}$. By contrast with the $\mathrm{K}_{2} \mathrm{O}$ distributions, $\mathrm{TiO}_{2}$ abundances in the older phase are slightly higher than those of normal tholeiites, whereas those of the younger phase vulcanism are more typically tholeiitic.

In addition to differences between the $\mathrm{TiO}_{2}$ and $\mathrm{K}_{2} \mathrm{O}$ contents in the two phases, there are differences between $\mathrm{Fe}$ and $\mathrm{Mg}$ contents at given silica values, although on a $\mathrm{FeO}$ (total $\mathrm{Fe}$ ) $/ \mathrm{MgO}$ plot both sets fall in the same band (Fig. 10). On a plot of $\mathrm{FeO}^{\mathrm{t}} / \mathrm{MgO}$ against $\mathrm{SiO}_{2}$ the values for the first phase plot in a single band, but $\mathrm{FeO}^{\mathrm{t}} / \mathrm{MgO}$ is lower for basalts of the younger phase (Figs. 8 and 9). Second phase samples show two diverging trends. In one, the ratio increases slowly with increasing silica, in more or less similar fashion to the trend for the first phase for $>55 \% \mathrm{SiO}_{2}$. In the other, the $\mathrm{FeO}^{\mathrm{t}} / \mathrm{MgO}$ ratio increases to a greater degree relative to the $\mathrm{SiO}_{2}$ content. These two trends may represent two volcanic sources in the arc between which the oxygen fugacity differed.

Of the 15 basement rocks analyzed from Sites 454 and 456 (Wood et al., this volume), 13 have $\mathrm{FeO}^{\mathrm{t}} / \mathrm{MgO}$ ratios of about 1 or less, as do the basic glasses of the first phase; the ratios are thus lower than those of the basalts of the second phase. These basement rocks closely resemble basaltic glasses of the first phase. $\mathrm{TiO}_{2}$, for instance, is about $1 \%$, and $\mathrm{K}_{2} \mathrm{O}$ at $50 \% \mathrm{SiO}_{2}$ is 0.1 to $0.6 \%$. $\mathrm{FeO}^{t}$ is lower and $\mathrm{MgO}$ is higher. The second 

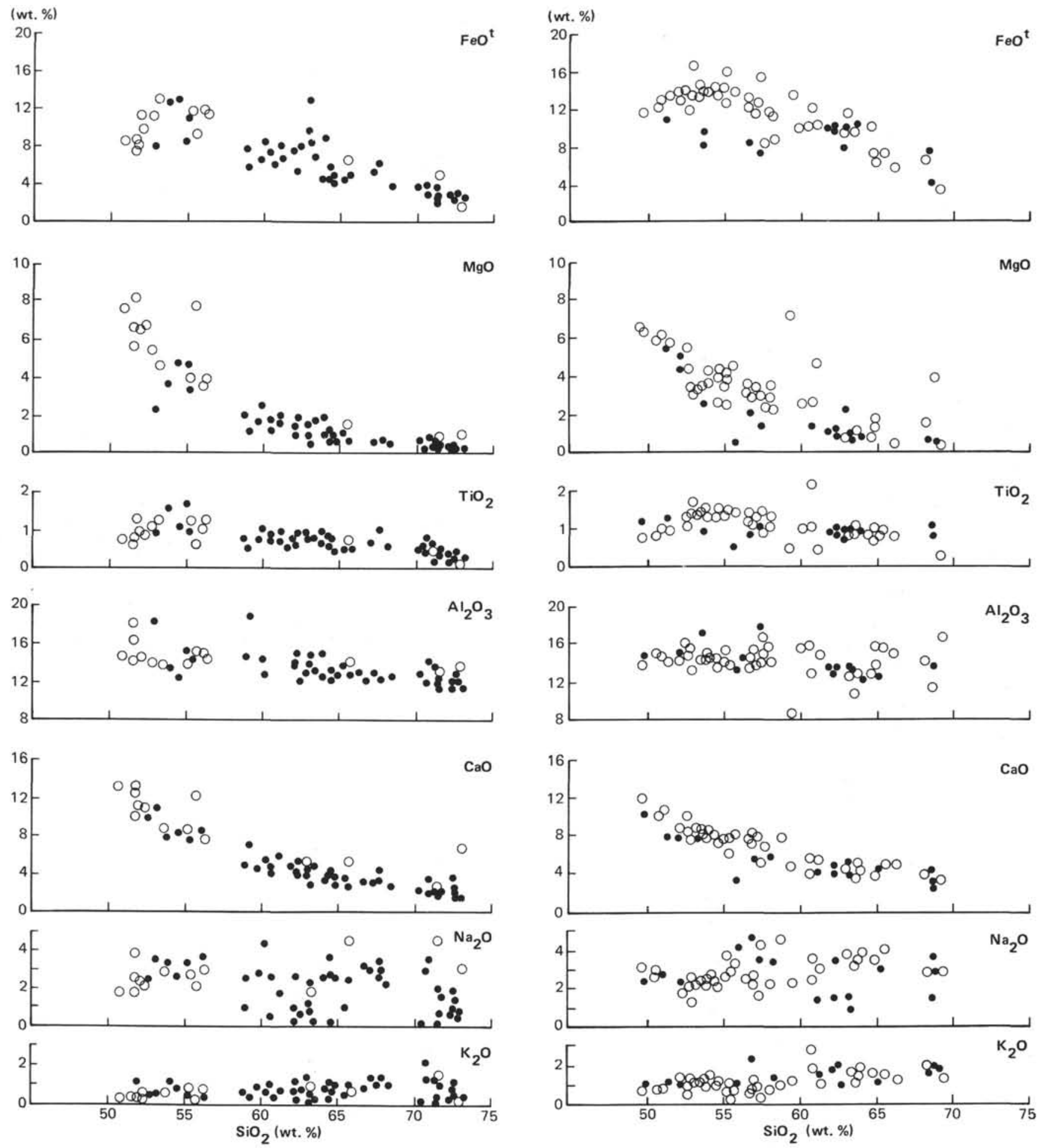

Figure 6. Weight percentages of major elements plotted against weight percentage of silica for glass samples from Hole 453 sediments older than 2 m.y. (first volcanic phase) (Cores 18-42). Symbols as in Figure 5.

phase basaltic glasses have slightly lower $\mathrm{TiO}_{2}$ than the basement rocks, higher $\mathrm{K}_{2} \mathrm{O}$, and significantly higher $\mathrm{FeO}^{\mathrm{t}}$ and $\mathrm{MgO}$. We will compare these further.

Unfortunately no analyses are available for the oldest seafloor in the Mariana Trough (uppermost Miocene),

Figure 7. Weight percentages of silica for glass samples from Hole 453 sediments between $200,000 \mathrm{y}$, and $2 \mathrm{~m}$.y. old (second volcanic phase) (Cores 1-12). Symbols as in Figure 5.

but from major element data from the lower and upper Pleistocene seafloor rocks from Sites 454 and 456 , it seems possible to conclude that the parents of the first phase volcanics and the seafloor basalts were similar. The major element compositions of the Mariana Trough seafloor basalts are for the most part similar to N-type 
(wt. \%)

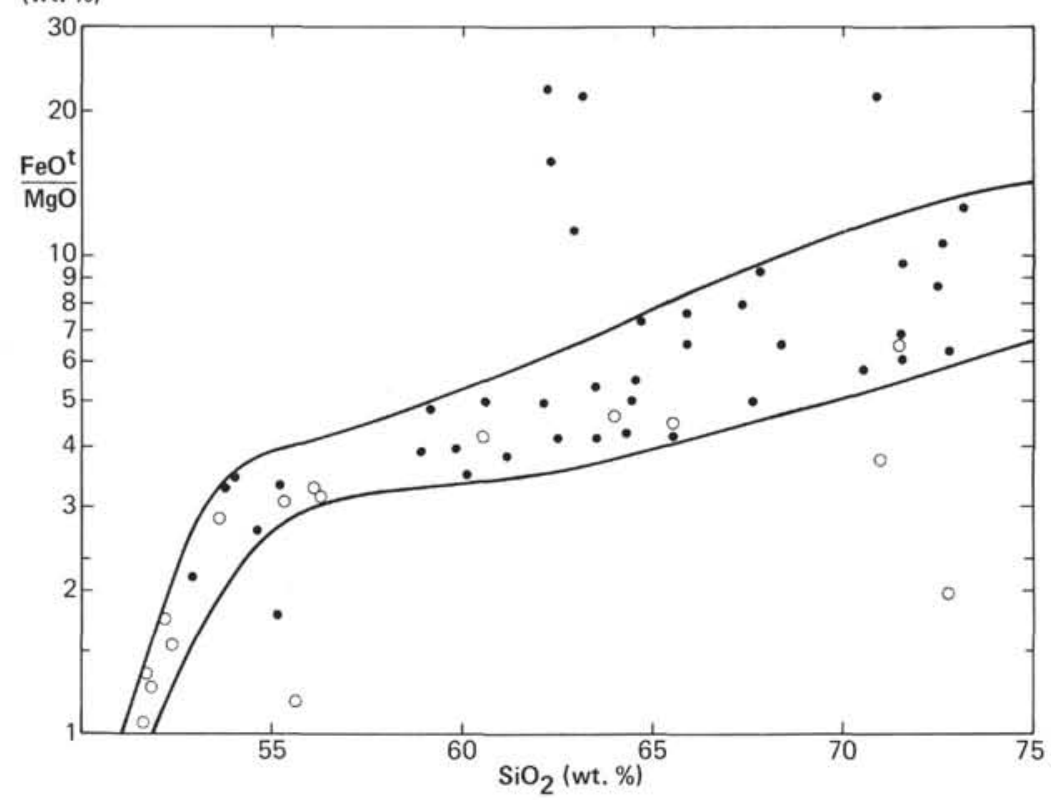

Figure 8. Weight percentage of $\mathrm{FeO}^{\mathrm{t}}$ (total $\mathrm{Fe}$ as $\mathrm{FeO}$ )/weight percentage of $\mathrm{MgO}$ plotted against weight percentage of silica for the first volcanic phase glasses (Hole 453, Cores 18-42). Symbols as in Figure 5.

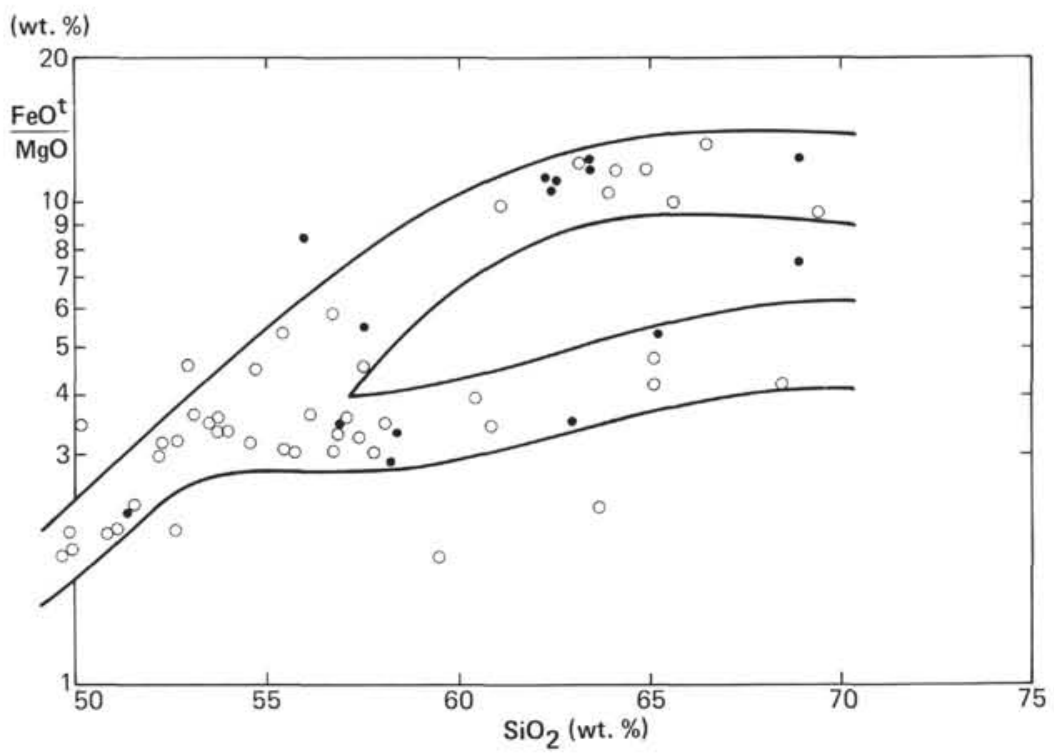

Figure 9. Weight percentage of $\mathrm{FeO}^{\mathrm{t}}$ (total $\mathrm{Fe}$ as $\mathrm{FeO}$ )/weight percentage of $\mathrm{MgO}$ plotted against weight percentage of silica for the second volcanic phase glasses (Hole 453, Cores 1-12). Symbols as in Figure 5.

MORB. Although their trace element chemistry includes some N-type MORB units, they show predominantly island arc affinities.

Mattey et al. (1980) analyzed 9 samples of clasts from the volcanic unit 11 to $9.5 \mathrm{~m}$.y. old at Site 451 on the West Mariana Ridge. Their silica contents range from 48 to $58 \%$, and $\mathrm{FeO}^{\mathrm{t}} / \mathrm{MgO}$ ratios vary from 0.9 to 1.9 . Their $\mathrm{MgO}$ contents are significantly lower than those of the glasses from the trough sediments, as are their $\mathrm{CaO}$ contents. $\mathrm{Al}_{2} \mathrm{O}_{3}$ contents are significantly higher
(18 to $20 \%$ as against 11 to $16 \%$ in the sediment glasses). Their trace element abundances show affinities with the calc-alkalic magma series.

\section{Comparison of Sites 453 and 454 Glasses}

The presence of a preponderance of green glass with a high refractive index in sediments from Site 454 raises the question of whether the glass was derived from the seafloor basalts with which the lower part of the sequence is interbedded. Although the samples have a lim- 


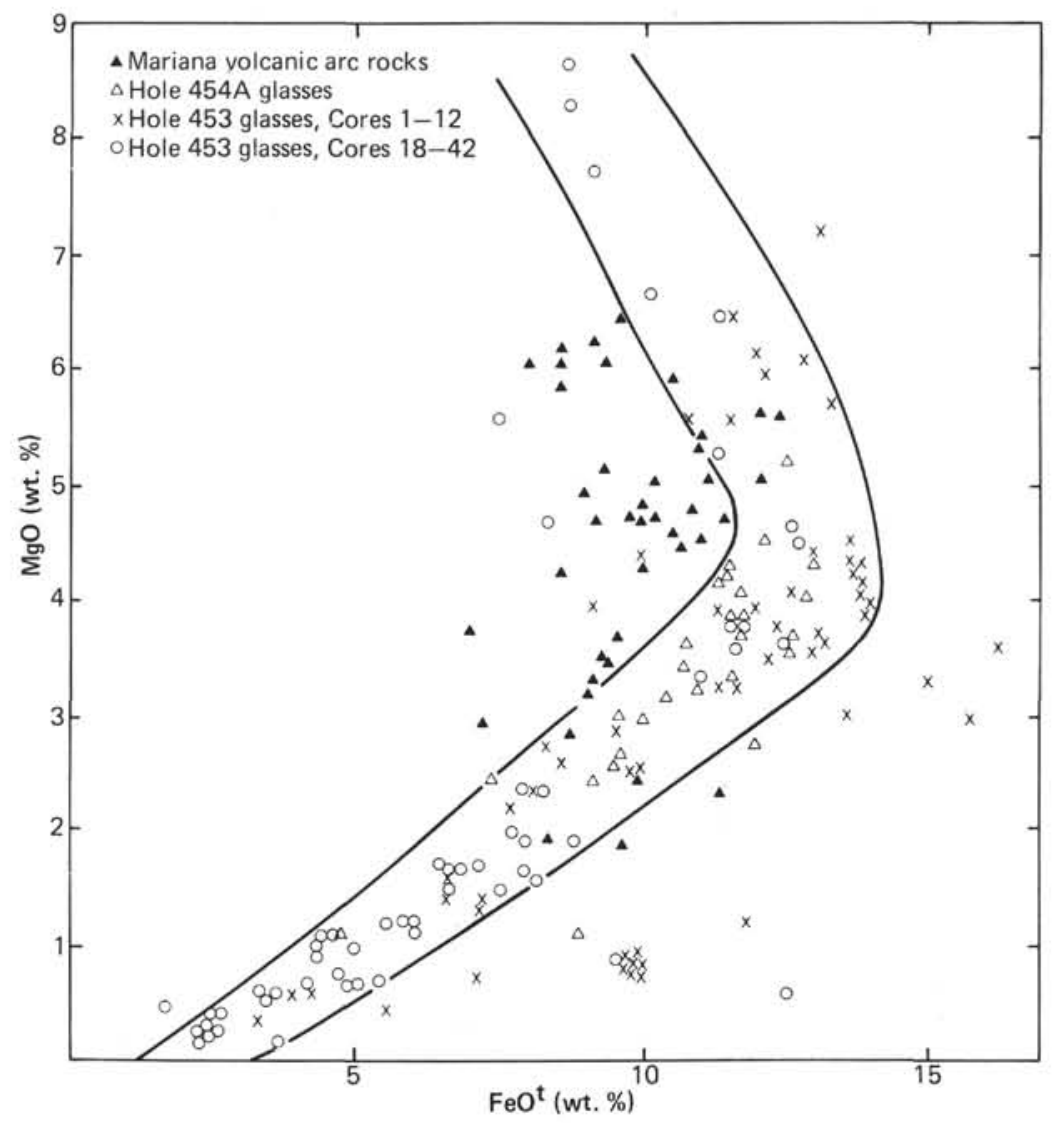

Figure 10. Weight percentage of $\mathrm{MgO}$ plotted against $\mathrm{FeO}^{\mathrm{t}}$ (total $\mathrm{Fe}$ as $\mathrm{FeO}$ ) for Mariana volcanic area rocks (third volcanic phase) and Cores 18-42, Hole 453 (first volcanic phase).

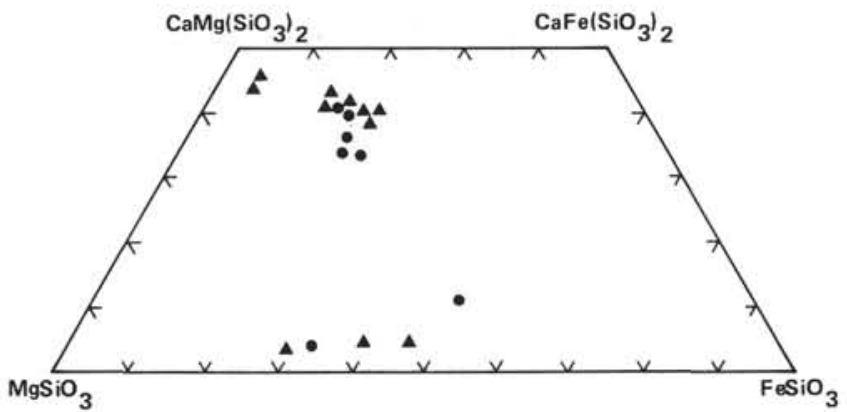

Figure 11. Microprobe analyses of pyroxene grains from Hole 453 sediments. ( $\mathbf{\Delta}=$ first volcanic phase samples, $\boldsymbol{\theta}=$ second phase samples.)

ited $\mathrm{SiO}_{2}$ range, the glasses have higher silica than the seafloor basalts. The same is true for the $\mathrm{K}_{2} \mathrm{O}$ contents. The chemical similarities are rather to the glasses of the second phase at Site 453 than to the basement rocks.

\section{Comparison of Sites 453 and 454 Glasses with the Mariana Island Arc Rocks and the Tonga Arc}

Analyses are available of about 40 rocks from the islands of the active island arc (Larson et al., 1974; Stern, 1979; Dixon and Batiza, 1979; Meijer, in press). Their modal silica content averages $51 \%$ and there are five analyses over $55 \% \mathrm{SiO}_{2}$ and five below $50 \%$. They would be expected to correlate with the glasses at the top of the holes at Sites 453 and 454. Although the glasses and the island igneous rocks are in fact similar in many respects, there are also significant differences. The most important of these differences is apparent when the plots of $\mathrm{FeO}^{\mathrm{t}}$ against $\mathrm{MgO}$ are compared (Fig. 10). The analyses of the island rocks plot in a different field (they are richer in $\mathrm{MgO}$ ) and do not show the distinctive enrichment in iron of both phases of volcanism at Site 453 . When compared with the major element percentages of the second phase at Site 453, other differences are also apparent. $\mathrm{Al}_{2} \mathrm{O}_{3}$ at Site 453 is lower (almost entirely $<16 \%$ vs. almost entirely $>16 \%$ ), but $\mathrm{K}_{2} \mathrm{O}, \mathrm{TiO}_{2}$, and $\mathrm{FeO}^{t}$ are higher.

Major element data thus indicate that three volcanic phases can be distinguished, the last of which commenced within the last 200,000 years. The first two are island arc tholeiites in the sense of Jakeš and Gill (1970), whereas the third is not typical of the island arc tholeiitic series, showing only a slight iron enrichment trend more typical of calc-alkaline suites (Dixon and Batiza, 1979). The third phase is not represented in the sediment samples. The resemblances and differences can be emphasized by comparing the CIPW norms of the basaltic members (about $51 \% \mathrm{SiO}_{2}$ ) of the first and second trough phases, the arc rocks from various islands, and 
Table 2. Microprobe analyses of detrital pyroxene grains from Site 453 sediments, Hole 453.

\begin{tabular}{lcccccccccr}
\hline $\begin{array}{c}\text { Sample } \\
\text { (interval in cm) }\end{array}$ & $\mathrm{SiO}_{2}$ & $\mathrm{TiO}_{2}$ & $\mathrm{Al}_{2} \mathrm{O}_{3}$ & $\mathrm{FeO}$ & $\mathrm{MnO}$ & $\mathrm{MgO}$ & $\mathrm{CaO}$ & $\mathrm{Na}_{2} \mathrm{O}$ & $\mathrm{K}_{2} \mathrm{O}$ & Total \\
\hline $453-2-3,36-38$ & 50.86 & 0.67 & 2.57 & 13.55 & 0.58 & 15.24 & 15.79 & 0.12 & - & 99.39 \\
& 49.23 & 0.66 & 2.69 & 14.75 & 0.53 & 14.98 & 15.57 & 0.34 & - & 98.77 \\
& 51.17 & 0.70 & 3.21 & 12.82 & 0.41 & 15.24 & 17.59 & 0.25 & - & 101.43 \\
$453-6-1,40-42$ & 48.86 & 0.26 & 0.51 & 30.53 & 1.10 & 12.80 & 4.98 & - & - & 99.12 \\
$453-10-2,36-38$ & 53.33 & 0.66 & 0.90 & 11.50 & 0.54 & 14.53 & 19.76 & 0.57 & 0.03 & 101.83 \\
$453-12, \mathrm{CC}$ & 52.61 & 0.29 & 1.26 & 21.28 & 0.62 & 23.21 & 1.76 & - & - & 101.02 \\
$453-15-3,38-40$ & 52.11 & 0.42 & 1.42 & 11.84 & 0.46 & 14.02 & 19.26 & 0.25 & - & 99.86 \\
& 51.96 & 0.56 & 1.56 & 14.76 & 0.44 & 14.06 & 17.32 & - & - & 100.98 \\
$453-24-2,47-48$ & 53.50 & 0.25 & 0.92 & 19.60 & 0.97 & 23.65 & 1.59 & - & - & 100.31 \\
$453-27-2,21-23$ & 52.81 & 0.20 & 0.77 & 24.65 & 0.95 & 19.66 & 1.92 & - & - & 100.96 \\
$453-33-2,71-72$ & 51.30 & 0.47 & 1.32 & 14.37 & 0.60 & 13.24 & 18.63 & 0.28 & - & 100.28 \\
& 50.94 & 0.23 & 0.69 & 28.22 & 1.15 & 17.02 & 1.70 & - & - & 99.97 \\
$453-37-5,31-32$ & 53.84 & 0.16 & 1.41 & 3.45 & - & 17.64 & 0.09 & - & - & 100.15 \\
& 51.39 & 0.46 & 1.64 & 13.58 & 0.50 & 14.01 & 19.57 & 0.29 & - & 101.74 \\
$453-42-2,6-7$ & 51.10 & 0.42 & 2.20 & 9.82 & 0.32 & 15.00 & 10.36 & 0.29 & - & 99.52 \\
& & & & & & & & & $\mathrm{Cr}_{2} \mathrm{O}_{3}$ & \\
& 53.35 & 0.08 & 1.44 & 3.28 & 0.09 & 17.82 & 23.35 & 0.22 & 0.84 & 100.47 \\
\hline & & & & & & & & & &
\end{tabular}

Table 3. Microprobe analyses of glass grains from Site 454 sediments, Hole 454A.

\begin{tabular}{|c|c|c|c|c|c|c|c|c|c|c|c|}
\hline $\mathrm{SiO}_{2}$ & $\mathrm{TiO}_{2}$ & $\mathrm{Al}_{2} \mathrm{O}_{3}$ & $\mathrm{FeO}$ & $\mathrm{MnO}$ & $\mathrm{MgO}$ & $\mathrm{CaO}$ & $\mathrm{Na}_{2} \mathrm{O}$ & $\mathrm{K}_{2} \mathrm{O}$ & $\mathrm{P}_{2} \mathrm{O}_{5}$ & $\mathrm{Cl}_{2}$ & Total \\
\hline \multicolumn{12}{|c|}{ Sample 454A-1-3, 93-94 cm } \\
\hline 52.74 & 1.25 & 14.71 & 12.12 & 0.15 & 4.50 & 8.92 & 2.62 & 1.35 & 0.13 & 0.13 & 98.61 \\
\hline 53.70 & 1.14 & 16.1 & 11.55 & 1.32 & 3.29 & 7.83 & 2.25 & 1.68 & 0.21 & 0.20 & 99.27 \\
\hline 54.54 & 0.90 & 17.68 & 9.15 & 0.20 & 2.47 & 8.27 & 2.47 & 1.32 & 0.18 & 0.16 & 97.58 \\
\hline 54.82 & 0.48 & 22.52 & 4.62 & 0.05 & 1.01 & 10.06 & 3.52 & 0.81 & 0.09 & 0.06 & 98.05 \\
\hline \multicolumn{12}{|c|}{ Sample $454 \mathrm{~A}-4-2,33-39 \mathrm{~cm}$} \\
\hline 54.74 & 1.08 & 15.42 & 10.72 & 0.21 & 3.62 & 7.79 & 3.58 & 0.78 & 0.07 & 0.25 & 98.28 \\
\hline 55.53 & 0.95 & 15.41 & 9.59 & 0.31 & 2.64 & 5.90 & 5.63 & 1.05 & 0.18 & 0.42 & 97.61 \\
\hline 55.93 & 0.94 & 15.31 & 9.66 & 0.37 & 2.63 & 5.78 & 3.98 & 1.07 & 0.25 & 0.48 & 96.36 \\
\hline 56.65 & 1.09 & 15.39 & 10.63 & 0.18 & 3.41 & 7.33 & 4.04 & 0.95 & 0.15 & 0.30 & 100.12 \\
\hline 57.09 & 1.24 & 15.07 & 10.37 & 0.19 & 3.14 & 7.20 & 3.96 & 0.87 & 0.11 & 0.29 & 99.53 \\
\hline 57.54 & 1.00 & 15.03 & 9.48 & 0.19 & 3.00 & 6.12 & 4.10 & 0.98 & 0.19 & 0.35 & 97.98 \\
\hline 57.86 & 1.02 & 14.66 & 9.93 & 0.18 & 2.94 & 6.73 & 3.73 & 0.83 & 0.03 & 0.34 & 98.25 \\
\hline 65.81 & 0.95 & 13.49 & 8.80 & 0.24 & 1.09 & 4.02 & 4.05 & 1.75 & 0.16 & 0.54 & 100.90 \\
\hline \multicolumn{12}{|c|}{ Sample 454A-8-2, 23-25 } \\
\hline 53.43 & 1.03 & 15.19 & 11.46 & 0.25 & 4.20 & 8.41 & 3.38 & 0.79 & 0.13 & 0.22 & 98.49 \\
\hline 54.79 & 1.16 & 15.38 & 11.67 & 0.24 & 3.88 & 8.14 & 3.64 & 0.94 & 0.11 & 0.14 & 100.19 \\
\hline 55.05 & 1.22 & 15.63 & 11.73 & 0.17 & 4.03 & 8.27 & 3.52 & 0.83 & 0.13 & 0.24 & 100.82 \\
\hline 55.16 & 1.18 & 15.47 & 11.43 & 0.24 & 4.13 & 8.10 & 3.47 & 0.86 & 0.19 & 0.20 & 100.45 \\
\hline 55.32 & 1.35 & 16.06 & 11.53 & 0.24 & 4.32 & 8.37 & 3.81 & 0.81 & 0.09 & 0.19 & 102.09 \\
\hline \multicolumn{12}{|c|}{ Sample $454 A-13-1,50-53$} \\
\hline 53.23 & 1.23 & 14.34 & 12.46 & 0.19 & 5.20 & 9.01 & 2.59 & 0.78 & 0.11 & 0.13 & 99.27 \\
\hline 53.45 & 1.29 & 14.02 & 12.94 & 0.23 & 4.29 & 7.99 & 3.52 & 0.76 & 0.16 & 0.23 & 98.87 \\
\hline 54.11 & 1.13 & 14.62 & 11.71 & 0.17 & 3.67 & 7.93 & 2.38 & 0.82 & 0.09 & 0.20 & 96.85 \\
\hline 54.73 & 1.21 & 14.25 & 12.82 & 0.22 & 4.02 & 8.01 & 2.47 & 0.80 & 0.11 & 0.17 & 98.81 \\
\hline 54.80 & 1.35 & 13.65 & 12.56 & 0.25 & 3.52 & 7.35 & 3.75 & 0.89 & 0.06 & 0.21 & 98.40 \\
\hline 54.81 & 1.25 & 14.53 & 12.52 & 0.30 & 3.68 & 8.18 & 2.83 & 0.85 & 0.09 & 0.21 & 99.27 \\
\hline 55.32 & 1.08 & 16.45 & 10.86 & 0.18 & 3.27 & 8.51 & 4.00 & 0.65 & 0.13 & 0.19 & 100.65 \\
\hline 55.42 & 1.13 & 15.09 & 11.55 & 0.20 & 3.86 & 8.21 & 3.44 & 0.76 & 0.13 & 0.20 & 100.00 \\
\hline 56.59 & 1.20 & 15.49 & 11.97 & 0.17 & 2.72 & 7.76 & 3.81 & 0.91 & 0.21 & 0.20 & 101.02 \\
\hline 56.85 & 0.91 & 16.66 & 7.27 & 0.14 & 3.41 & 7.19 & 3.53 & 1.29 & 0.16 & 0.20 & 97.62 \\
\hline 59.60 & 1.72 & 14.07 & 9.47 & 0.13 & 2.54 & 6.07 & 4.80 & 1.96 & 0.32 & 0.33 & 101.01 \\
\hline
\end{tabular}

the average of DSDP analyses of seafloor basalts from Site 454 (Table 4). The arc rocks are all quartz normative (2-6\%) -in fact, a sample from Agrigan (Stern, 1979) containing $48.7 \% \mathrm{SiO}_{2}$ still calculates as quartz normative-and normative quartz increases with increasing $\mathrm{SiO}_{2}$. Calculations of norms for typical samples from the first and second phases (assuming an $\mathrm{Fe}_{2} \mathrm{O}_{3}$ content of $1.5 \%$ ) reveals a slight undersaturation (if in the first phase a slight loss of $\mathrm{Na}_{2} \mathrm{O}$ is assumed). At a lit- the over $54.5 \% \mathrm{SiO}_{2}$, corresponding to the $\mathrm{FeO}^{\mathrm{t}}$ maximum for the Site 453 glasses, the rocks are strongly quartz normative (9\%). The average of the basalt samples from Site 454 is olivine normative but more so than the two basaltic glasses from Site 453 quoted in Table 4 .

Fractionation has been suggested to explain the compositional variations in Mariana Islands rocks (Stern, 1979; Dixon and Batiza, 1979). The same mechanism can be invoked for the glasses studied here, although no 

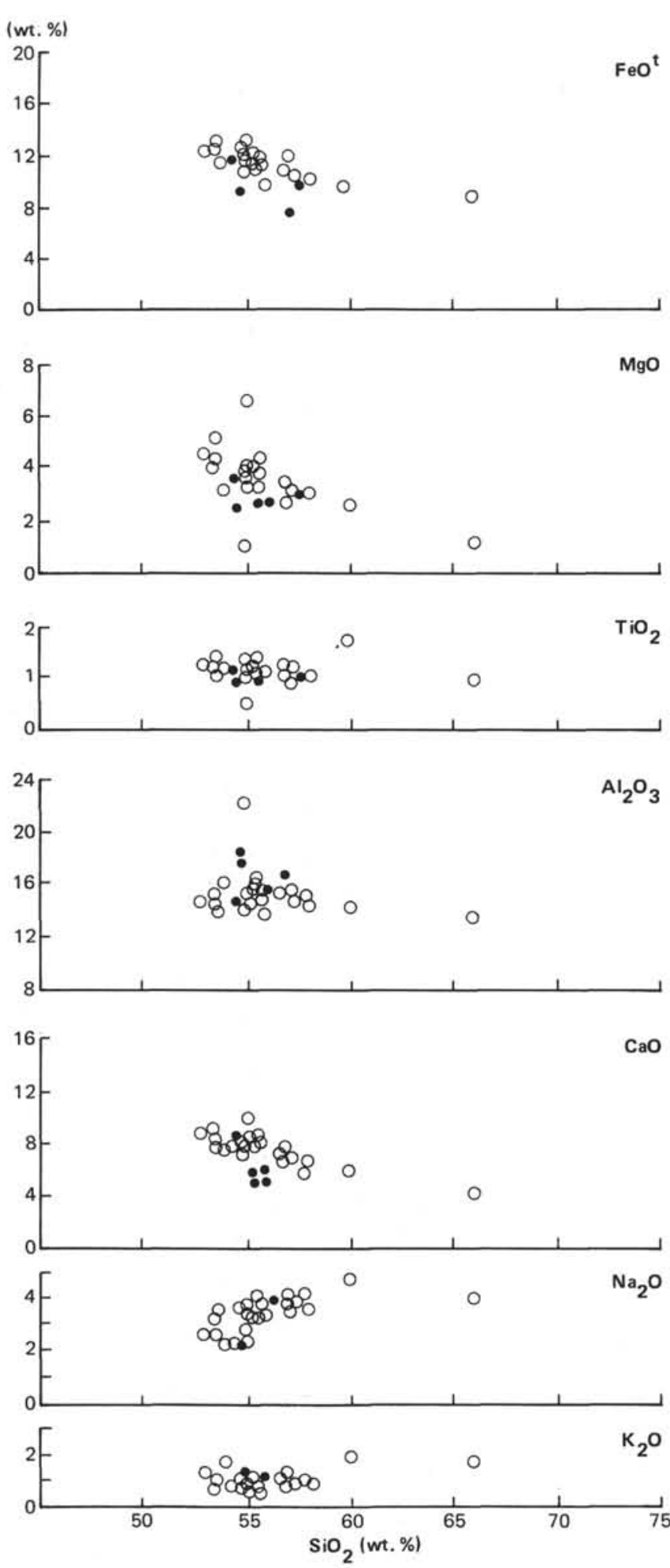

Figure 12. Weight percentage of major elements plotted against weight percentage of silica for glass samples from Hole 454A. Symbols as in Figure 5 .

mathematical modelling has yet been attempted. Qualitatively it appears that fractionation initially separated olivine rich in $\mathrm{MgO}$, diopsidic clinopyroxene, and anorthitic plagioclase, with delay in the precipitation of titanomagnetite to between 54 and $55 \% \mathrm{SiO}_{2}$. Later, orthopyroxene or pigeonite probably precipitated. Although the analytical information is compatible with a fractionation model, the proportions of the rocks observed in the glasses are not. Nevertheless, the approximately even frequency distribution of silica percentages rather than an abundance of basic glasses may be due to an origin in explosive vulcanism or to differentiation in magma chambers, permitting only the more acid lava to reach the surface.

The resemblance between the Mariana glasses and the Tonga volcanics is very close, as would be expected from the nearly identical settings of the Mariana and the Tonga arcs (especially during the first phase). There is a strong iron enrichment trend in the Tonga rocks (Ewart et al., 1973; Ewart et al., 1977). $\mathrm{K}_{2} \mathrm{O}$ and $\mathrm{TiO}_{2}$ values are similar to those of the first Mariana phase, but iron content is more scattered and tends to be a little higher. The close correlation with the first phase is of interest genetically since the Lau Basin to the West of the Tonga-Kermadec Arc-the analog of the Mariana Trough-is only about $5 \mathrm{~m} . \mathrm{y}$. old (Weissel, 1977) and the first phase of vulcanism in the Mariana Arc lasted at least 3 m.y.

\section{CONCLUSIONS}

A succession of three chemically distinct suites of arc volcanic phases can be identified. The oldest phase of vulcanism began at least $5 \mathrm{Ma}$, possibly as much as 4 m.y. after the commencement of formation of the Mariana Trough 9.5 Ma, and ended about $2 \mathrm{Ma}$. The second phase ended within the last $200,000 \mathrm{y}$., when a third phase commenced.

The first sediments deposited at Site 453, representing the first volcanic phase, were laid down $5 \mathrm{Ma}$ when the Mariana Trough was only a little over $110 \mathrm{~km}$ wide. The spreading of the trough commenced about $9.5 \mathrm{Ma}$ (assuming a basement age of about $8 \mathrm{~m} . \mathrm{y}$. at the site, as determined by seafloor magnetic anomalies; see Bleil, this volume). The oldest sample studied (about $4.8 \mathrm{~m} . \mathrm{y}$.) shows a considerable range in composition of the arcderived glasses, which suggests that the arc volcanics had been established and that fractionation had produced compositions distinctly different from those of the earlier vulcanism on the West Mariana Ridge. If the volcanoes occupied their present location relative to the site of rifting, at the time these oldest known arc volcanic sediments were deposited, the mantle upwelling responsible for Mariana Trough seafloor formation and the arc volcanoes must have been less than $50 \mathrm{~km}$ apart. If there was a significant time lapse between emplacement and extrusion, as indicated by the compositional range of the arc rocks, the two magma sources must have been considerably closer when the first batch of magma was emplaced in the arc. It is likely, therefore, that both the interarc basin seafloor and the lavas of the earliest arc vulcanism were derived from the same source; indeed, the major element data presented here indicate the resemblance between the earliest volcanic ashes and at least the Pleistocene seafloor. Unfortunately no seafloor rock samples from the oldest crust in the basin are available for comparison; nor are there 
Table 4. Selected analyses and CIPW norms.

\begin{tabular}{|c|c|c|c|c|c|c|c|c|c|c|}
\hline & & \multirow{2}{*}{$\begin{array}{c}\text { Mariana } \\
\text { Trough } \\
\text { Seafloor } \\
\text { Hole 454A } \\
\text { (Average) }\end{array}$} & \multicolumn{2}{|c|}{$\begin{array}{l}\text { First Volcanic } \\
\text { Phase (Hole 453) }\end{array}$} & \multicolumn{2}{|c|}{$\begin{array}{l}\text { Second Volcanic } \\
\text { Phase (Hole 453) }\end{array}$} & \multicolumn{4}{|c|}{$\begin{array}{l}\text { Third Volcanic Cycle } \\
\text { Mariana Active Volcanoes }\end{array}$} \\
\hline & & & $\begin{array}{c}\text { Basalt } \\
\text { (Core 18) }\end{array}$ & $\begin{array}{l}\text { Basaltic } \\
\text { Andesite } \\
\text { (Core 42) }\end{array}$ & $\begin{array}{l}\text { Basalt } \\
\text { (Core 1) }\end{array}$ & $\begin{array}{l}\text { Basaltic } \\
\text { Andesite } \\
\text { (Core 10) }\end{array}$ & Agrigan $^{d}$ & Guguan $^{\mathrm{e}}$ & Pagan $^{f}$ & Sarigan $^{f}$ \\
\hline \multicolumn{2}{|c|}{$\mathrm{SiO}_{2}$} & 50.6 & 51.58 & 54.69 & 50.93 & 54.55 & 50.9 & 50.88 & 51.0 & 51.5 \\
\hline \multicolumn{2}{|c|}{$\mathrm{TiO}_{2}$} & 0.98 & 0.71 & 1.12 & 0.88 & 1.35 & 0.80 & 0.76 & 0.97 & 0.78 \\
\hline \multicolumn{2}{|c|}{$\mathrm{Al}_{2} \mathrm{O}_{3}$} & 14.9 & 14.56 & 12.46 & 14.84 & 13.45 & 16.6 & 19.36 & 17.0 & 15.7 \\
\hline \multicolumn{2}{|c|}{$\mathrm{Fe}_{2} \mathrm{O}_{3}$} & 1.09 & $1.50^{\mathrm{a}}$ & $2.57^{\mathrm{b}}$ & $1.50^{\mathrm{a}}$ & $2.80^{\mathrm{b}}$ & 2.99 & 2.22 & 3.4 & 4.3 \\
\hline \multicolumn{2}{|c|}{$\mathrm{FeO}$} & 7.17 & 7.28 & 10.29 & 10.71 & 10.93 & 8.33 & 7.10 & 8.3 & 5.4 \\
\hline \multicolumn{2}{|c|}{$\mathrm{MnO}$} & 0.13 & 0.19 & 0.31 & 0.22 & 0.32 & 0.22 & 0.16 & 0.21 & 0.04 \\
\hline \multicolumn{2}{|c|}{$\mathrm{MgO}$} & 9.79 & 8.27 & 4.67 & 5.94 & 4.32 & 5.10 & 4.67 & 4.7 & 6.1 \\
\hline \multicolumn{2}{|c|}{$\mathrm{CaO}$} & 11.42 & 13.35 & 8.49 & 10.36 & 8.00 & 10.46 & 11.42 & 10.0 & 10.6 \\
\hline \multicolumn{2}{|c|}{$\mathrm{Na}_{2} \mathrm{O}$} & 2.81 & $2.40^{c}$ & 2.6 & 2.69 & 2.29 & 2.57 & 2.37 & 2.9 & 2.4 \\
\hline \multicolumn{2}{|c|}{$\mathrm{K}_{2} \mathrm{O}$} & 0.33 & 0.20 & 0.81 & 0.74 & 1.08 & 0.73 & 0.40 & 0.78 & 0.59 \\
\hline \multicolumn{2}{|c|}{$\mathrm{P}_{2} \mathrm{O}_{5}$} & 0.10 & 0.06 & 0.12 & n.d. & n.d. & 0.17 & 0.13 & 0.24 & 0.05 \\
\hline \multicolumn{2}{|c|}{$Q^{2}$} & - & - & 9.1 & - & 8.2 & 2.4 & 3.1 & 4.7 & 6.0 \\
\hline \multicolumn{2}{|l|}{ Or } & 1.9 & 1.2 & 4.8 & 4.4 & 6.4 & 4.4 & 2.3 & 4.6 & 3.5 \\
\hline \multicolumn{2}{|l|}{$\mathrm{Ab}$} & 23.8 & 20.3 & 22.0 & 22.8 & 19.3 & 22.0 & 20.0 & 20.0 & 20.3 \\
\hline \multicolumn{2}{|l|}{ An } & 27.1 & 29.3 & 19.9 & 26.2 & 23.2 & 32.0 & 41.0 & 33.5 & 30.3 \\
\hline \multirow{2}{*}{$\mathrm{Di}$} & $\mathrm{Di}$ & 13.9 & 16.4 & 8.6 & 10.2 & 5.9 & 8.7 & 6.3 & 6.0 & 10.9 \\
\hline & $\mathrm{He}$ & 9.6 & 12.3 & 9.9 & 10.8 & 7.4 & 7.3 & 5.9 & 5.9 & 6.6 \\
\hline \multirow{2}{*}{ Hy } & En & 6.2 & 9.4 & 7.7 & 8.1 & 8.2 & 17.0 & 8.5 & 8.5 & 8.9 \\
\hline & Fs & 2.8 & 5.1 & 10.2 & 9.5 & 13.9 & 8.8 & 7.4 & 8.3 & 3.0 \\
\hline \multirow{2}{*}{$\mathrm{Ol}$} & Fo & 6.6 & 3.1 & - & 1.3 & - & - & - & - & - \\
\hline & $\mathrm{Fa}$ & 3.6 & 1.8 & - & 1.7 & - & - & - & - & - \\
\hline \multicolumn{2}{|l|}{$\mathrm{Mt}$} & 1.6 & 2.2 & 3.7 & 2.2 & 4.1 & 4.4 & 3.2 & 4.9 & 6.2 \\
\hline \multicolumn{2}{|l|}{ Il } & 1.9 & 1.3 & 2.1 & 1.7 & 2.6 & 1.5 & 1.4 & 1.8 & 1.5 \\
\hline \multicolumn{2}{|l|}{ Ap } & 0.2 & 0.1 & 0.2 & - & - & 0.4 & 0.3 & 0.6 & 0.1 \\
\hline
\end{tabular}

a Assumed $\mathrm{Fe}_{2} \mathrm{O}_{3}$.

b Assuming $\mathrm{Fe}_{2} \mathrm{O}_{3}: \mathrm{FeO}=1: 4$ owing to enrichment in $\mathrm{Fe}_{2} \mathrm{O}_{3}$.

c Increased from 1.92, $\mathrm{Na}_{2} \mathrm{O}$ loss assumed.

d Stern (1979).

e Dixon and Batiza (1979).

f Larson et al. (1974).

trace element or isotopic data available for the glasses. As the trough became wider the geochemical major element differences between the seafloor rocks and the arc rocks became greater. The first phase was probably initially more or less basaltic but had become considerably differentiated by $4 \mathrm{~m} . \mathrm{y}$. after the commencement of rifting, eventually producing basaltic to highly acid lavas. The second phase commenced when the trough was about $200 \mathrm{~km}$ wide and the spreading ridge was about 85 $\mathrm{km}$ from the volcanic arc. It did not last as long as the first ( 2 m.y. to ?200,000 y.), but the magma had a higher $\mathrm{Fe} / \mathrm{Mg}$ ratio at the basic end of the series, higher $\mathrm{K}_{2} \mathrm{O}$, higher $\mathrm{TiO}_{2}$, and a smaller range of silica contents. Compared with the second phase the most recent magma ( $<200,000$ y.) has a lower $\mathrm{Fe} / \mathrm{Mg}$ ratio and lower $\mathrm{FeO}$ and $\mathrm{MgO}$, and its iron enrichment trend is slight, more closely resembling a calc-alkaline trend. The $\mathrm{Al}_{2} \mathrm{O}_{3}$ is higher and $\mathrm{K}_{2} \mathrm{O}$ and $\mathrm{TiO}_{2}$ are lower. Less differentiation has occurred so far in this phase than in the previous two.

With the passage of time, the volcanics changed in composition from interarc-basin tholeiite to calc-alkalic, possibly indicating a fading of the influence of the basin spreading mechanism on arc vulcanism.

\section{ACKNOWLEDGMENTS}

We would like to thank K. Moran and D. Benson for their assistance with microprobe work and Prof. T. Vallance and Drs. E. Leitch and E. Middlemost for helpful discussion. The manuscript was reviewed by Drs. R. Scott and J. Natland, and we are grateful for their suggestions.

\section{REFERENCES}

Dixon, T. H., and Batiza, R., 1979. Petrology and chemistry of recent lavas in the northern Marianas: Implications for the origin of island arc basalts. Contrib. Mineral. Petrol., 70:167-181.

Ewart, A., Brothers, R. N., and Mateen, A., 1977. An outline of the geology, geochemistry, and the possible petrogenetic evolution of the volcanic rocks of the Tonga-Kermadec-New Zealand Island arc. J. Volcanol. Geotherm Res., 2:205-250.

Ewart, A., Bryan, W. B., and Gill, J. B., 1973. Mineralogy and geochemistry of the younger volcanic islands of Tonga, southwest Pacific. J. Petrol., 14:429-465.

Jakes, P. and Gill, J., 1970. Rare earth elements and the island arc tholeiite series. Earth Planet. Sci. Lett., 9:17-28.

Larson, E. E., Reynolds, R. L., Merril, R., et al., 1974. Major-element petrochemistry of some extrusive rocks from the volcanically active Mariana Islands. Bull. Vulcanol., 38:11-38.

Mattey, D. P., Nicholas, G. M., and Tarney, J., 1980. The geochemistry, mineralogy and petrology of basalts from the West Philippine Sea and Parece Vela Basins and from the Palau-Kyushu and West Mariana Ridges, Deep Sea Drilling Project Leg 59. In Kroenke, L., Scott, R. B., et al., Init. Repts. DSDP, 59: Washington (U.S. Govt. Printing Office), 753-800.

Meijer, A., in press. Regional distribution and character of active andesitic volcanism (b) Mariana-Volcano Islands. In Thorpe, R. S. (Ed.), Orogenic Andesites and Related Rocks: New York (Wiley).

Scott, R. B., Kroenke, L., Zakariadze, G., et al., 1980. Evolution of the South Philippine Sea: Deep Sea Drilling Project Leg 59 results. In Kroenke, L., Scott, R. B., et al., Init. Repts. DSDP, 59: Washington (U.S. Govt. Printing Office), 803-816.

Stern, J. R., 1979. On the origin of andesite in the Northern Mariana Island arc: Implications from Agrigan. Contrib. Mineral. Petrol., 68:202-219.

Weissel, J. K., 1977. Evolution of the Lau Basin by the growth of small plates. In Talwani, M., and Pitman, W. C. (Eds.), Island Arcs, Deep-Sea Trenches and Back-Arc Basins: Maurice Ewing Series, Vol. 1: Washington (American Geophysical Union), 429-436. 